\title{
Effect of fertiliser application and cutting regime on temporal differentiation of mesic semi-natural grassland vegetation
}

\author{
Jure Čop, Klemen Eler \\ University of Ljubljana, Biotechnical Faculty, Department of Agronomy, Ljubljana, Slovenia
}

\begin{abstract}
To address biodiversity and agronomic value of grasslands, we attempted to determine the effect of management regimes on temporal plant species diversity of Arrhenatherion grassland vegetation over a 7-year period. In a split-plot experiment, three cutting regimes (traditional 2-cut system, modified and regular 4-cut systems) and five fertilisation regimes [i) zero; ii) phosphoruspotassium (PK); iii) cattle slurry; iv) nitrogen-PK (NPK) plus cattle slurry; v) NPK] were assigned to the main plots and the subplots, respectively. Significant temporal changes in plant species composition, abundance of functional groups, plant richness and Shannon index were found for most investigated regimes. The effects of fertilisation regimes on all investigated parameters were much stronger than cutting regimes. Generally, two distinct pathways of sward compositional development were found, depending on whether the mineral $\mathrm{N}$ was added or not. Differentiation in the
\end{abstract}

Correspondence: Jure Čop, University of Ljubljana, Biotechnical Faculty, Department of Agronomy, Jamnikarjeva 101, SI-1000 Ljubljana, Slovenia.

Tel.: +386.(0).1320.3274.

E-mail: jure.cop@bf.uni-lj.si

Key words: Arrhenatherion grassland; cattle slurry; mineral nitrogen; PK fertiliser; plant species diversity.

Acknowledgements: the research was supported by the Slovenian Research Agency from the research core funding No P4-0085 and by the Ministry for Agriculture, Forestry and Food (research project J44224). We thank Boštjan Medved Karničar for his excellent support in managing the field experiment and William Schrader for English-language editing of the manuscript.

Contributions: the authors contributed equally.

Conflict of interests: the authors declare no potential conflict of interests.

Received for publication: 12 February 2019.

Revision received: 17 May 2019.

Accepted for publication: 18 May 2019.

${ }^{C}$ Copyright: the Author(s), 2019

Licensee PAGEPress, Italy

Italian Journal of Agronomy 2019; 14:1405

doi:10.4081/ija.2019.1405

This article is distributed under the terms of the Creative Commons Attribution Noncommercial License (by-nc 4.0) which permits any noncommercial use, distribution, and reproduction in any medium, provided the original author(s) and source are credited. plant species composition and abundance of functional groups started in the second year and continued with the progress of the experiment. A quite distinct pattern of change in the plant species composition was found for PK where initially higher abundance of legumes triggered the sward development similar to the slurryfertilisation regime. The fertilisation with high $\mathrm{N}$ rates caused temporal decrease in species richness and Shannon index. Other fertilisation treatments did not affect these two diversity parameters in a seven-year period. The cutting regimes did not temporally differentiate the sward regarding plant species composition and abundance of functional groups. They affected only plant species composition in the seventh year and indicated some effect on the temporal change of Shannon index.

\section{Introduction}

Semi-natural grasslands, characterised by their self-sown indigenous species, are still present in European traditional and organic farming systems. Their main management features are infrequent cutting with or without autumn grazing (i.e. up to four defoliations) or extensive grazing with moderate or zero fertiliser inputs. However, their area has substantially decreased since the mid- $20^{\text {th }}$ century due to agricultural intensification or abandonment. The former has led to impoverished plant communities or conversion to arable land, while the latter has led towards the secondary succession to woodlands (Vassilev et al., 2011; Hooftman and Bullock, 2012; Wesche et al., 2012; Ridding et al., 2015).

Agricultural intensification has been the predominant factor in the loss of mesic semi-natural grasslands in Europe (Waesch and Becker, 2009; Hooftman and Bullock, 2012). In agriculturally productive areas, these grasslands have been converted to arable lands to a large extent. Elsewhere, they have been intensified by increased fertiliser application and defoliation frequency along with occasional herbicide application and re-sowing of productive forage grasses and legumes.

It is well known that fertiliser application immediately increases herbage growth rate and yield of a grassland with nutrient deficiencies, but these effects are more pronounced for competitive plant species (e.g. grasses) than for others (Wesche et al., 2012). As a consequence of this growth asymmetry, plant diversity of grassland decreases (DeMalach et al., 2017). In a longer time period, it also generally reduces plant species richness (e.g. Tilman et al., 1994; Silvertown et al., 2006; Dickson and Gross, 2013; Hejcman et al., 2014). However, a particular response of grassland vegetation to fertiliser application can be specific depending on site conditions and composition of vegetation (Socher et al., 2013). For example, infertile grassland soils with low nutrient content and/or low $\mathrm{pH}$ are usually occupied by rather small numbers of stress tolerant plant species with low evenness 
(Silvertown, 1980; Čop et al., 2009). Improving such soils by fertiliser application and liming often increases vascular plant diversity (Tilman et al., 1994; Zechmeister et al., 2003), but changes of the type of grassland community might be undesirable from the conservation perspective.

Nitrogen (N) usually has the largest effects on composition and structure of grassland vegetation (Wesche et al., 2012). Addition of $\mathrm{N}$ is expressed in a rapid change of the relative abundance of species and later in generally reduced plant diversity (Tilman, 1987; Soons et al., 2017). The effect of $\mathrm{N}$ is mainly indirect as for other limiting nutrients, mediated by increased productivity, where plants compete primary for light and space (Socher et al., 2012). Phosphorus (P) is the second most important nutrient regarding plant diversity of grassland, but its effect is much less than that of N (Soons et al., 2017). Janssens et al. (1998) reported a negative relation between soil $\mathrm{P}$ content and plant species richness and that the highest richness was found below the optimum content in soil at 50 to $80 \mathrm{mg}$ available $\mathrm{P} \mathrm{kg}^{-1}$ (acetate + EDTA extraction). Potassium $(\mathrm{K})$ is considered a less important factor affecting plant diversity of grassland. The field experiments suggest that plant composition of grassland is quite insensible to $\mathrm{K}$ addition (Elberse et al., 1983; Hejcman et al., 2007; van Dobben et al., 2017).

Cutting regimes can significantly affect plant diversity of grassland and related sward structure, i.e. height and bulk density (e.g. Čop et al., 2009; Petersen and Isselstein, 2015). However, their effects on diversity are generally less profound and less straightforward than those of fertilisation regimes. Based on survey studies, Socher et al. (2013) and Zechmeister et al. (2003) reported that increasing cutting frequency in the range of one to four cuts per season has similar or less negative effect on plant species richness of mesic grassland than fertilisation regimes. In such studies, however, it is difficult to completely disentangle the effect of cutting frequency from the effect of fertiliser application. The effect of cutting frequency can be opposite from the above mentioned, resulting in higher species richness in four-cut grassland than two-cut grassland where moderate fertiliser rate was equal for both (Kramberger et al., 2015).

The objectives of this study were to establish the effects of different combinations of fertilisation and cutting regimes on temporal differentiation of: i) plant species composition; ii) relative abundance of functional groups; iii) species richness; and iv) Shannon diversity index of moderately managed Arrhenatherion grassland on potentially fertile soil. For plant species composition, seven-year cumulative differences between the treatments were also tested. The study will contribute to the knowledge of temporal plant diversity of mesic semi-natural grasslands under different management regimes intended for silage or hay.

\section{Materials and methods}

The field experiment was carried out in the pre-Alpine region of Slovenia $\left(46^{\circ} 03^{\prime} \mathrm{N}, 14^{\circ} 28^{\prime} \mathrm{E}, 300 \mathrm{~m}\right.$ a.s.1.) during the period 2011-2017. Mesic semi-natural grassland on the experimental site belongs to Arrhenatherion alliance. Prior to the start of the experiment, the grassland had been moderately managed for more than 20 years, meaning one application of mineral fertiliser in early spring at the approximate rate of $60 \mathrm{~kg} \mathrm{~N}, 26 \mathrm{~kg}$ P and $50 \mathrm{~kg} \mathrm{~K}$ $\mathrm{ha}^{-1}$ year $^{-1}$ and four defoliations of herbage over the season, i.e. one early spring and one autumn lenient grazing by sheep and two hay cuttings in mid-season.

\section{Soil and weather conditions}

Stagnic Eutric Cambisol (Drainic, Humic, Siltic) (WRB, 2015) at the field experimental site is approximately $110 \mathrm{~cm}$ deep with a moderately gleyed layer between $30 \mathrm{~cm}$ and $70 \mathrm{~cm}$ below the surface. The soil profile consists of silty loam in the upper $30 \mathrm{~cm}$ and silty clay loam in the lower $80 \mathrm{~cm}$. The parent material is carbonated deposits of sand and gravel. In the upper $6 \mathrm{~cm}$ soil layer, the initial $\mathrm{pH}\left(\mathrm{CaCl}_{2}\right)$ was 6.4 , and contents of available $\mathrm{P}$ and $\mathrm{K}$ (extracted in ammonium lactate) were $25 \mathrm{mg}$ and $104 \mathrm{mg} \mathrm{kg}^{-1}$ of dry soil, respectively. The reference ranges (low, medium, high) are: $<26,26-55,56-110 \mathrm{mg} \mathrm{P}$ and $<100,100-190,191-275 \mathrm{mg} \mathrm{K}$ $\mathrm{kg}^{-1}$ of dry soil. The soil is artificially drained by sub-surface drains.

The climate of the experimental site is moderately continental, modified by the Alps in the vicinity, and is characterised by its humidity and high seasonal variation of air temperature and precipitation. For the reference period between 1981 and 2010, the annual average air temperature and annual sum of precipitation are, respectively, $10.9^{\circ} \mathrm{C}$ and $1362 \mathrm{~mm}$, both measured at $2 \mathrm{~m}$ above the ground surface. Grassland vegetation at the experimental site often suffers from lack of moisture during mid-summer, as illustrated by the climograph (Figure 1). During the experimental period, there were two notable weather exceptions compared to the climograph: the first one in 2014 with very humid weather (total precipitation $1851 \mathrm{~mm}$ ) and rather typical distribution of precipitation during the summer and the second one in 2017 with quite dry and hot weather during most of the season and an extremely high amount of rainfall in September $(344 \mathrm{~mm})$.

\section{Experimental design and treatments}

The treatments were arranged in a split-plot design with four replicates. Three cutting regimes and five fertilisation treatments were assigned to main plots and sub-plots, respectively. A sub-plot size was $5 \times 2 \mathrm{~m}$. Description of treatments is shown in Table 1 . Additional experimental details: i) narrow strips between plot boundaries were maintained over the course of the experiment by applying Glyphosate herbicide once per year; ii) a cutter bar mower was used for cutting plots to a $5-\mathrm{cm}$ stubble height; iii)

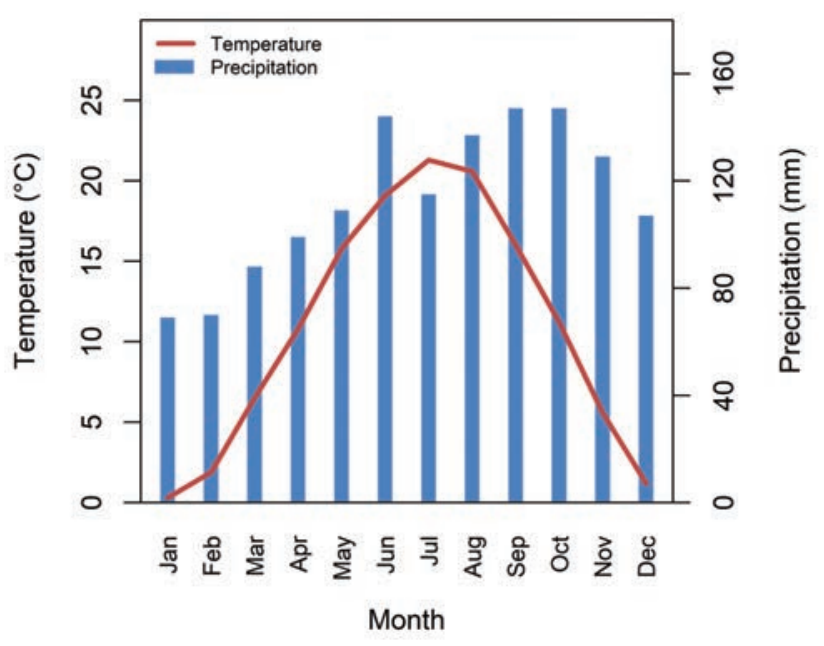

Figure 1. Climograph of a Ljubljana weather station $\left(46^{\circ} 4{ }^{\prime} \mathrm{N}\right.$, $14^{\circ} 31$ ', $299 \mathrm{~m}$ a.s.1.) for the period 1981-2010. The station is located near the experimental site. 
split-application of calcium ammonium nitrate fertiliser $(27 \% \mathrm{~N})$ was performed the first time in the third decade of March and then immediately after each cutting according to the plan; iv) each plot treated by cattle slurry (hereafter only slurry) was additionally sprayed by water in amount 1.5 times the applied amount of slurry. The purpose of this was to simulate slurry dilution.

\section{Yield measurement and botanical analyses}

Mown herbage from each sub-plot, including samples used for botanical analysis, was weighed. The fresh masses were converted to dry matter (DM) yields of herbage per ha using the data on DM contents. Over the course of the experiment, 336 vegetation surveys were carried out solely by the authors to ensure a consistent quality of data. Each sub-plot was analysed in the spring of each year except for the year of 2016 following the two-step BraunBlanquet approach. At the first step, we recorded plant species present. At the second step, cover-abundance of each species in the sward was visually estimated. The Braun-Blanquet scale with 6 classes $(+=<1 \%, 1=1-10 \%, 2=10-25 \%, 3=25-50 \%, 4=50$ $75 \%, 5=75-100 \%$ ) was used for the estimation. The relative abundance of the functional groups (grasses, legumes and forbs) in the experimental sward was determined separately using fresh herbage samples. Prior to the first season cut, a randomly selected herbage sample from a $0.5 \mathrm{~m}^{2}$ quadrat was taken from each sub-plot. It was immediately separated to the functional groups, which were then weighted to calculate their proportions in a sward.

\section{Data analyses}

For statistical analyses, all class values assigned to the listed species were converted to percentages of the respective class averages $(0.5 \%$ was used for + class $)$. Shannon diversity index (denoted hereafter as Shannon index) was calculated using the data of species proportions from the vegetation survey and the equation:

$$
H^{\prime}=-\sum_{i=1}^{S}(p i \times \ln p i)
$$

where $H^{\prime}$ is Shannon index, $S$ is number of species, and $p i$ is proportion of $i$ th species in a sward.
Temporal differentiations of the sward vegetation composition were assessed by detrended correspondence analysis (DCA). Permutational analysis of variance (PERMANOVA) was used to assess the overall significance of dissimilarities (Bray-Curtis distance) in the vegetation composition between different sampling years, fertilisation and cutting regimes and their interactions. For post-hoc pairwise comparison tests, PERMANOVA was used with Bonferroni correction to account for the number of tests performed. Proportions of grasses, legumes and forbs were analysed using the compositional data approach (Egozcue et al., 2003). Proportion values were transformed using isometric log-ratio, and the obtained values were jointly used in linear mixed model where plot was treated as a random factor, while sampling year, fertilisation and cutting regimes were treated as the fixed factors. The effects of the treatments and sampling year on the species number, Shannon index and herbage yield were tested using linear mixed models as described above.

Statistical analyses were performed in $\mathrm{R}$ environment ( $\mathrm{R}$ Core Team, 2017) using the libraries vegan, compositions and pairwise Adonis. If not indicated otherwise, significance level of 0.05 was used for testing.

\section{Results}

\section{Herbage yield}

The average annual herbage DM yield obtained in the study during the whole experimental period is shown on Figure 2. The yield was significantly affected by fertilisation regime $(\mathrm{P}<0.001)$, cutting regime $(\mathrm{P}=0.009)$ and year $(\mathrm{P}<0.001)$. The interactions were not significant except that one of fertilisation $\times$ year which was marginal $(\mathrm{P}=0.042)$. The fertilisation treatments significantly increased the yield in the following order: zero fertiliser (control), slurry, PK, slurry $+\mathrm{N}_{120} \mathrm{PK}, \mathrm{N}_{220} \mathrm{PK}$. The yield differences among cutting regimes were small but significant between 2-cut system and each of the other two systems. Herbage yields decreased most in the years when shortage of soil moisture in spring occurred on the experimental site.

Table 1. Cutting regimes $[\mathrm{A}-\mathrm{C}]$ and fertilisation treatments [1-5] applied in the experiment. Cutting regimes

[A] Traditional 2-cut system denoted as 2 cuts (first cut 5-10 Jun, second cut 10-20 Aug, additional aftermath cutting in early autumn to simulate late season grazing) [B] Modified 4-cut system denoted as 4 (3) cuts (4-cut system in each of two consecutive years, 3-cut system with the delayed first cut in each third year - first cut 25-30 Jun, second cut 10-15 Aug, third cut 20-25 Oct); 3-cut system was performed in the years of 2011, 2014 and 2017

[C] Regular 4-cut system denoted as 4 cuts (first cut 10-20 May, second cut 25 Jun-5 Jul, third cut 10-20 Aug, fourth cut 20-30 Oct) Fertilisation treatments

[1] Unfertilised control (zero fertilisers were used)

[2] PK fertiliser (31 kg P plus $174 \mathrm{~kg} \mathrm{~K} \mathrm{ha}^{-1}$ year-1 applied in the third decade of March)

[3] Slurry (22 $\mathrm{t} \mathrm{ha}^{-1}$ of cattle slurry surface-spread in the third decade of March; average composition: $2.60 \mathrm{~g} \mathrm{~N}, 0.51 \mathrm{~g} \mathrm{P}$ and $2.35 \mathrm{~g} \mathrm{~K} \mathrm{kg-1}$ of slurry); from the year of 2015 onward the additional application was done $\left(20 \mathrm{t} \mathrm{ha}^{-1}\right.$ of cattle slurry applied in the second half of August); total slurry rates $22 \mathrm{tha}^{-1}$ year ${ }^{-1}$ in the years of 2011-2014 and $42 \mathrm{t} \mathrm{ha}^{-1}$ year-1 in the years of 2015-2017

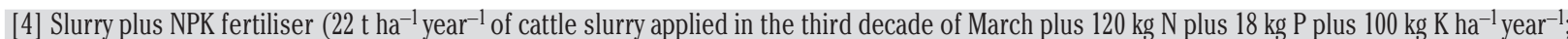
split-application of $\mathrm{N}: 50: 70 \mathrm{~kg}$ in traditional 2-cut system, 0:40:40 kg in modified 4-cut system when 3-cuts conducted and 0:40:40:40 kg in regular 4-cut system)

[5] NPK fertiliser (220 kg N plus $31 \mathrm{~kg}$ P plus $174 \mathrm{~kg} \mathrm{~K} \mathrm{ha}^{-1}$ year-1 applied in the third decade of March; split-application of N: 110:110 kg in traditional 2-cut system, 60:60:50 kg in modified 4-cut system when 3-cuts conducted and 60:60:50:50 kg in regular 4-cut system)

When 3-cut system was performed the annual amounts of $\mathrm{N}$ from mineral fertiliser were reduced by $40 \mathrm{~kg}$ [treatment 4 ] and $50 \mathrm{~kg} \mathrm{ha}^{-1}$ [treatment 5 ]. 


\section{Temporal differentiation of species composition}

The study focused on temporal differentiation of Arrhenatherion grassland vegetation under different management treatments. The DCA ordination of 336 vegetation surveys produced eigenvalues of $0.254,0.225,0.123$ and 0.118 for the first four axes, respectively. Since the first two axes explain a relatively large percentage of variability in species $\times$ plot matrix $(66.5 \%)$ and the third relatively small $(17.1 \%)$ we only used first two DCA axes in forthcoming ordinations. The length of the first axis is 2.51 which indicates relatively short species gradient and comparatively large similarity between all vegetation samples (Figure 3). The DCA plot of all samples also shows that between-plot variability of the experimental sward vegetation slightly increased with the treatment years, and that there is noticeable general shift of vegetation composition throughout treatment years.

The vegetation composition of the treated sward significantly changed under all fertilisation and cutting regimes compared to the initial composition, and the shift increased with time (Figure 4). It was most pronounced for NPK fertilisation and least for PK fertilisation with all other regimes between these extremes.

Comparison of the DCA ordination diagrams reveals that fertilisation regimes temporarily affected whole plant composition of the experimental sward differently and much more strongly than cutting regimes. The fertilisation effects show grouping for unfertilised control, slurry and PK treatment on one side and for NPK treatments with or without slurry on the other side. In the latter two treatments, added amounts of NPK nutrients were roughly similar. The plant composition pattern of sward treated with PK is, however, quite distinctive with peculiar development in the early years of investigation. The effect of slurry application on temporal plant composition development was weak in comparison to unfertilised control over the first four experimental years when quite a small amount was added (22 $\mathrm{t}$ of slurry $\mathrm{ha}^{-1}$ year $\left.^{-1}\right)$. In the subsequent three years, differences between these two treatments increased partly due to an almost double rate of slurry application (42 t of slurry ha $^{-1}$ year $^{-1}$; added in two split applications). Composition of the sward changed similarly under all cutting regimes over the course of the experiment (Figure 4). Yet, its pattern under tradition-

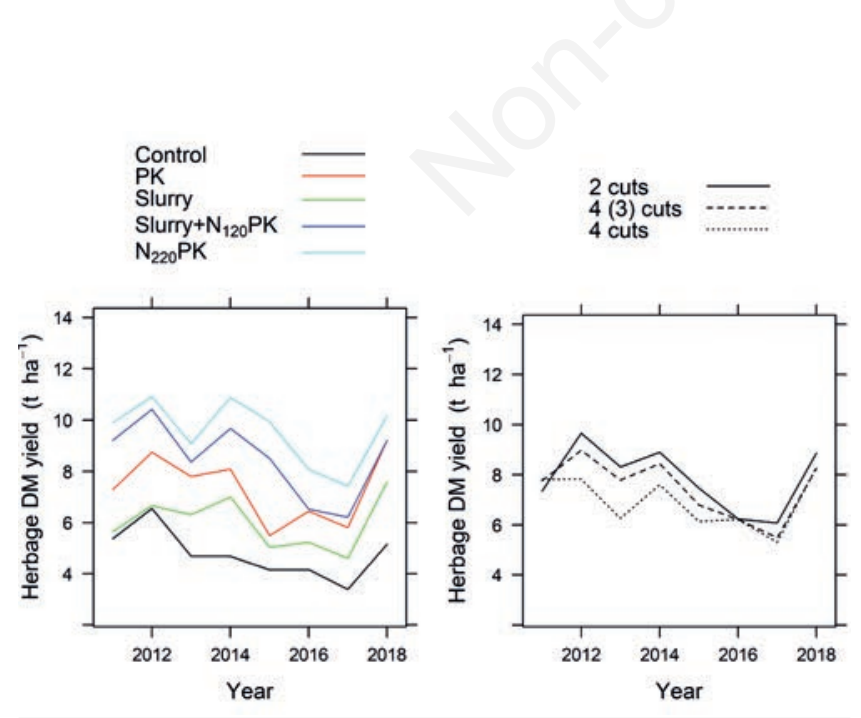

Figure 2. Annual herbage dry matter (DM) yield of the Arrbenatherion grassland subjected to the different management treatments for the period 2011-2018. The data were averaged for each fertilisation treatment over all cutting regimes (left) and for each cutting regime over all fertilisation treatments (right). al 2-cut system is less directional than the other two patterns. According to PERMANOVA, the temporal differences in plant composition of the experimental sward were significantly affected by fertilisation and cutting as well as by interactions between both factors and between each factor and year.

Pairwise PERMANOVA comparisons of the sward vegetation composition subjected to the fertilisation and cutting regimes revealed non-significant differences between pair treatments within each factor in the first experimental year, while they were confirmed in the seventh year (P values not shown). Based on these comparisons, only one list of ten most abundant species is shown for the first year, and eight lists are shown for the seventh year (Table 2).

In the first year, Lolium perenne prevailed in the sward under either fertilisation treatment being present in an average proportion of $26 \%$. On the average basis, it was followed by Poa trivialis and Trifolium pratense, with $10 \%$ and $8 \%$, respectively. Other species were much less abundant and common for Arrhenatherion grassland. In the seventh year, the experimental sward differentiated in two distinct groups regarding fertilisation: the unfertilised control and sward treated with slurry on one side and swards treated with NPK with or without slurry on the other side. In the first case, the leading species were Leontodon hispidus, Prunella vulgaris and Festuca arundinacea, present in average proportions of $21 \%, 16 \%$ and $14 \%$, respectively. In the second case, the most abundant species were Dactylis glomerata, Festuca arundinacea and Lolium perenne, present in average proportions of $17 \%, 13 \%$ and $10 \%$, respectively. The sward treated with PK was quite similar to the one treated with slurry but significantly different from all others. Its foremost feature was the highest proportion of legumes in their composition averaged $34 \%$ for all plots. Species composition of the experimental sward was only moderately affected by the cutting treatments in the seventh year. A significant difference was

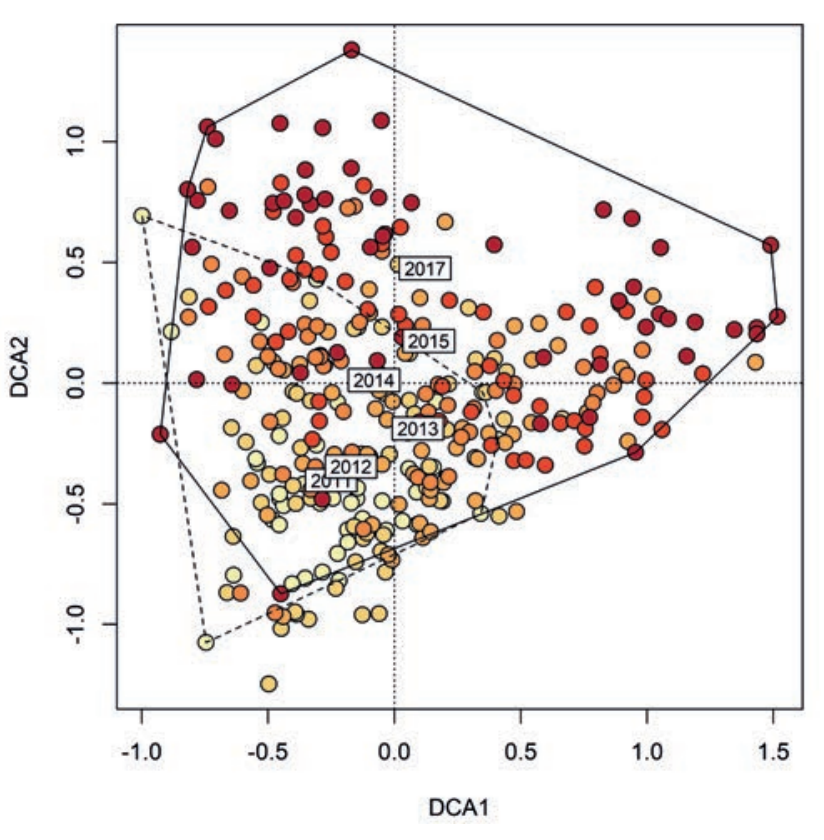

Figure 3. DCA ordination diagram of 336 vegetation surveys with centroid positions of the years (2011-2017). Sets of years' data are marked with different colour intensities (lightest for 2011, darkest for 2017). Data for 2011 and 2017 are bounded by dashed and solid lines, respectively. 
established only between traditional 2-cut and modified 4-cut systems $(\mathrm{P}<0.01)$. The plant community composition under traditional 2-cut system differed markedly from those under both other cutting systems in the content of Bromus hordeaceus, Agropyron repens and Trifolium pratense. They all ranked among the ten most abundant species in this infrequent cutting system only (Table 2).
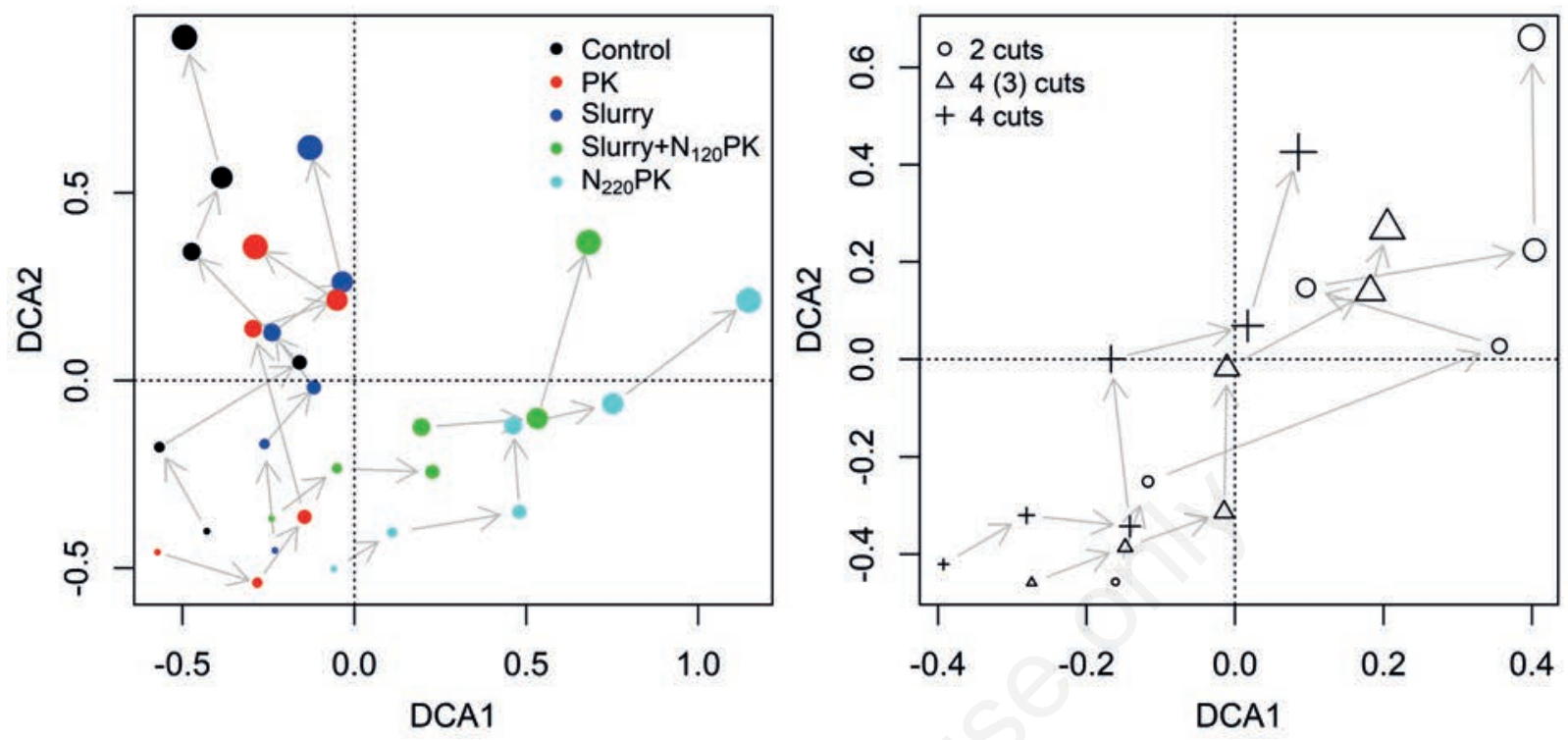

Figure 4. Temporal differentiation of the sward vegetation composition subjected to the different management treatments over the period 2011-2017. The vegetation surveys repeated from the year of 2011 (smallest symbols) until the year of 2017 (largest symbols) were averaged for each fertilisation treatment over all cutting regimes (left) and for each cutting regime over all fertilisation treatments (right).

Table 2. Ten most abundant plant species in the experimental sward in the first and the seventh experimental years subjected to the different fertilisation and cutting regimes. Proportions of the species in the sward were averaged across all treatments in the first year and across cutting treatments for fertilisation and vice versa for cutting regimes in the seventh year.

\begin{tabular}{|c|c|c|c|c|c|c|c|}
\hline Lolium perenne & 25.5 & Trifolium repens & 4.2 & Plantago lanceolata & 1.9 & Agrostis stolonifera & 1.6 \\
\hline Poa trivialis & 10.1 & Trifolium campestre & 3.2 & Leontodon hispidus & 1.7 & & \\
\hline Trifolium pratense & 7.9 & Prunella vulgaris & 2.2 & Poa pratensis & 1.7 & & \\
\hline 2017 - Unfertilised & & PK & & Slurry & & Slurry + $\mathrm{N}_{120} \mathrm{PK}$ & \\
\hline Leontodon hispidus & 26.2 & Leontodon hispidus & 14.4 & Leontodon hispidus & 16.3 & Festuca arundinacea & 13.6 \\
\hline Prunella vulgaris & 20.6 & Trifolium repens & 12.0 & Festuca arundinacea & 12.7 & Lolium perenne & 9.8 \\
\hline Lotus corniculatus & 16.2 & Lolium perenne & 11.9 & Prunella vulgaris & 11.9 & Poa pratensis & 9.8 \\
\hline Festuca arundinacea & 14.4 & Holcus lanatus & 9.2 & Holcus lanatus & 10.6 & Dactylis glomerata & 9.6 \\
\hline Lolium perenne & 10.1 & Vicia cracca & 8.8 & Lolium perenne & 10.6 & Holcus lanatus & 6.9 \\
\hline Holcus lanatus & 7.3 & Trifolium pratense & 7.6 & Festuca rubra & 7.8 & Leontodon hispidus & 6.9 \\
\hline Trifolium pratense & 6.7 & Festuca arundinacea & 7.4 & Lathyrus pratensis & 6.0 & Bromus hordeaceus & 5.8 \\
\hline Bromus hordeaceus & 3.6 & Prunella vulgaris & 6.3 & Poa pratensis & 5.3 & Glechoma hederacea & 4.6 \\
\hline Poa pratensis & 3.6 & Trifolium campestre & 6.0 & Trifolium pratense & 4.4 & Taraxacum officinale & 4.1 \\
\hline Trifolium repens & 3.1 & Potentilla reptans & 4.9 & Trifolium campestre & 3.7 & Crepis biennis & 3.9 \\
\hline $\mathrm{N}_{220} \mathrm{PK}$ & & Traditional 2-cut sy & em & Modified 4-cut syst & & Regular 4-cut syste & \\
\hline Dactylis glomerata & 25.2 & Festuca arundinacea & 12.8 & Lolium perenne & 15.5 & Leontodon hispidus & 15.8 \\
\hline Festuca arundinacea & 11.5 & Leontodon hispidus & 12.2 & Leontodon hispidus & 11.0 & Prunella vulgaris & 11.9 \\
\hline Lolium perenne & 10.6 & Dactylis glomerata & 9.2 & Holcus lanatus & 10.4 & Festuca arundinacea & 11.9 \\
\hline Agropyron repens & 8.0 & Prunella vulgaris & 8.8 & Festuca arundinacea & 10.1 & Lolium perenne & 10.0 \\
\hline Glechoma hederacea & 7.4 & Holcus lanatus & 8.8 & Dactylis glomerata & 9.7 & Dactylis glomerata & 7.7 \\
\hline Poa trivialis & 7.0 & Bromus hordeaceus & 7.9 & Poa pratensis & 7.5 & Lotus corniculatus & 6.9 \\
\hline Crepis biennis & 5.7 & Lolium perenne & 7.4 & Potentilla reptans & 6.2 & Poa pratensis & 6.0 \\
\hline Poa pratensis & 5.3 & Agropyron repens & 6.8 & Trifolium repens & 6.0 & Poa trivialis & 5.8 \\
\hline Holcus lanatus & 5.2 & Trifolium pratense & 5.8 & Prunella vulgaris & 5.6 & Trifolium repens & 5.6 \\
\hline Bromus hordeaceus & 5.0 & Lotus corniculatus & 5.5 & Taraxacum officinale & 4.5 & Lathyrus pratensis & 5.3 \\
\hline
\end{tabular}




\section{Functional groups (grasses, legumes and forbs)}

Proportions of grasses, legumes and forbs in the experimental sward were significantly affected by fertilisation treatments $(\mathrm{P}<0.001)$ but not by cutting regimes $(\mathrm{P}=0.215)$. The groups also significantly varied among the years $(\mathrm{P}<0.001)$, but these changes depended on the interaction with fertilisation treatments $(\mathrm{P}<0.001)$. Distinct proportions of the groups were caused by both treatments that included mineral nitrogen fertiliser, i.e. NPK and slurry plus NPK. Under these treatments, grasses increased at the expense of legumes and forbs. The diagrams of temporal changes of the functional groups illustrate the above mentioned effects and also show shift of these proportion in the sward under zero fertiliser and PK treatments in 2016 (Figure 5).

\section{Vegetation diversity parameters}

In all vegetation surveys, confined to $560 \mathrm{~m}^{2}$ of the experimental area, 92 vascular plant species were identified. On average, there were 27.8 species per plot of $10 \mathrm{~m}^{2}$ ranging from 16 to 37 species. Shannon index ranged from 1.58 to 2.69 with an average of 2.23 for all vegetation surveys. Fertilisation and cutting regimes

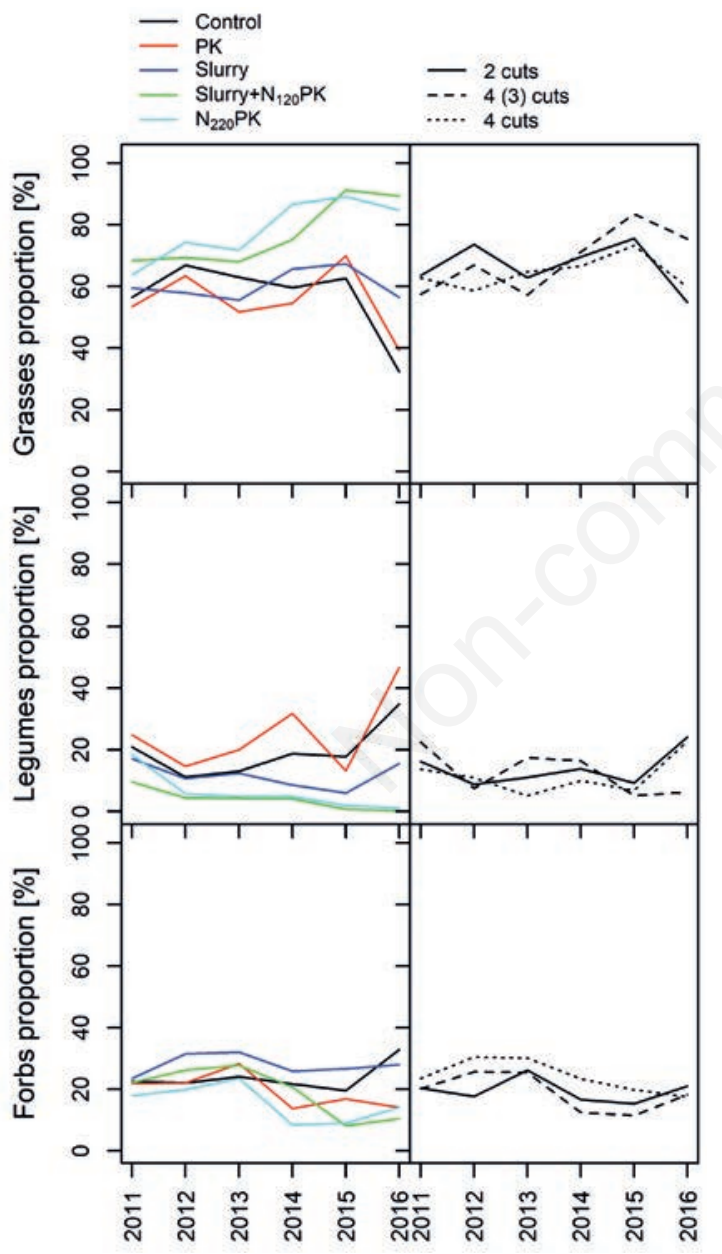

Figure 5. Temporal differentiation of the grassland vegetation under different management treatments with respect to the proportions of grasses, legumes and forbs in the spring prior to the first cut. The annual data (2011-2016) were averaged for each fertilisation treatment over all cutting regimes (left) and for each cutting regime over all fertilisation treatments (right). similarly affected temporal changes of species richness and Shannon index of the sward. Both parameters changed significantly under fertilisation regimes $(\mathrm{P}<0.001)$ but not under cutting regimes over the seven-year period. There was significant interaction between fertilisation and year $(\mathrm{P}<0.001)$ expressed in different magnitudes of change across fertilisation regimes. A species reduction in the treated sward occurred where mineral $\mathrm{N}$ was added with NPK with or without slurry in the seven-year period (Figure 6). It was also noticed that each addition of fertiliser, except the addition of PK in the case of species richness, reflected in increased variability of the records within particular treatments.

\section{Discussion}

A proper agricultural management of semi-natural grasslands is essential for their future existence. For this reason, our study dealt with the fertilisation and defoliation measures important for forage production and conservation of semi-natural grasslands on less intensive livestock farms. Comparing the applied treatment combinations, two can be considered as inappropriate (high $\mathrm{N}$ application-rate with or without slurry together with traditional 2cut system). Such managements are occasionally observed in practice and are thus scientifically relevant. Arrhenatherion grassland was chosen for the study because of its wide range across Europe, its importance for the biodiversity of the European agro-ecosystems and the need to better understand the threats, caused by management change, to this type of grassland (e.g. Zechmeister et al., 2003; Bosshard, 2015; Hülber et al., 2017).

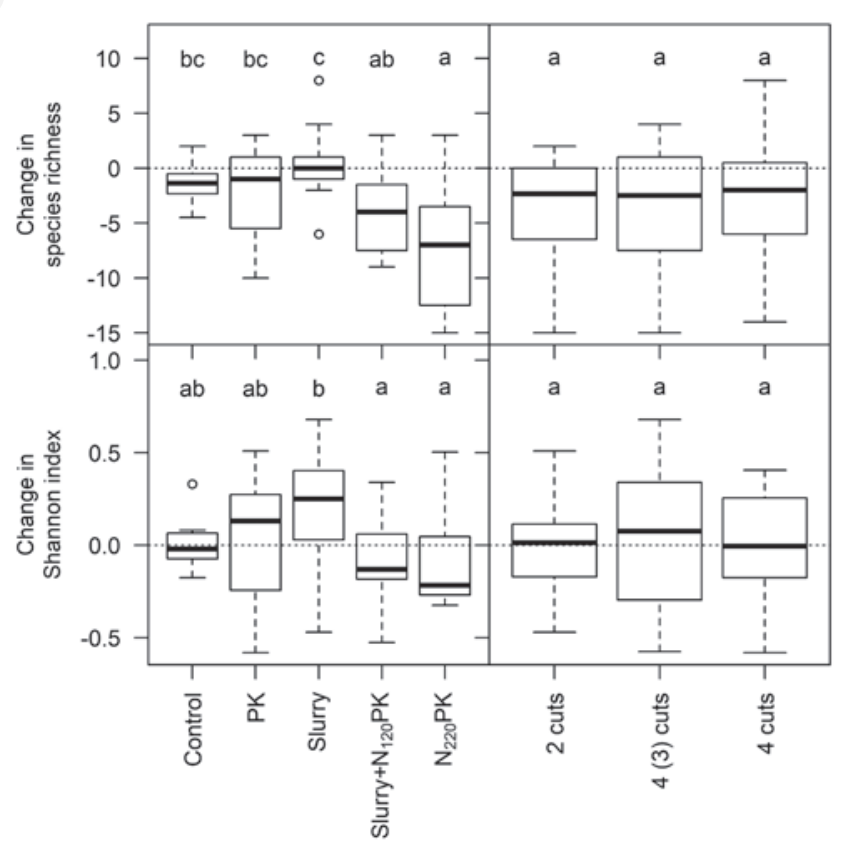

Figure 6. Change in species richness (top row) and Shannon index (bottom row) in the sward from 2011-2017, separately, for fertilisation and cutting regime treatments. Dashed horizontal line denotes no change. Letters above box-plots show significance of difference between treatments; those with the same letter are not significantly different at $\mathbf{P}=\mathbf{0 . 0 5}$. Interactions between factors were not significant. 


\section{Herbage yield}

Herbage DM yield of the studied grassland increased typically with increased nutrient rates applied by fertilisers. High sward production obtained by adding the largest amount of nutrients (both NPK treatments) requires 4-cut system to obtain high forage quality for dairy cows. The similar goal can be achieved with traditional 2-cut system in less fertilised sward where PK or slurry was applied. Regarding species richness and Shannon index these management systems mean still acceptable reduction of both diversity parameters in the first case and even their improvement it the second case compering to the unfertilised control. It is true that the yield was low when only PK or slurry was applied but such yields are achieved on many less intensive cattle farms what justifies the system from an economic standpoint.

\section{Temporal differentiation of species composition}

In spite of its divergence, the experimental sward in whole exhibited noticeable resistance to change in plant composition in response to the applied fertilisation and cutting regimes in the first seven-year period. This finding supports the previous literature evidence, which shows that grassland plant community subjected to different management treatments exhibits a large level of resistance to short-term compositional change (Galvanek and Lepš, 2008; Lepš, 2014). This is mainly the result of prolonged species resistance to competitive exclusion (Jung et al., 2014). The initial vegetation composition, adapted to moderate nutrient availability and utilisation, was another important factor for its generally weak response to the applied treatments. This was also pointed out for the fertiliser experiment on a productive alluvial Alopecurus pratensis meadow (Hejcman et al., 2014).

It is well established that fertiliser application is the most important management factor affecting sward species composition in semi-natural grasslands where seeding renovation is not applied (Chytrý et al., 2009; Socher et al., 2013; Lepš, 2014). This was also confirmed in our case, where temporal differentiation of Arrhenatherion grassland was affected much more by fertilisation than cutting regimes. However, our results pertain only to those regimes having practical relevance for less intensively managed grasslands and cannot be extrapolated.

Immediate availability and more efficient use of nutrients from mineral fertilisers compared to organic fertilisers, known especially for herbage production (Pötsch, 2008; Gaujour et al., 2012), were also reflected in the temporal plant community differentiation in this study. Early and pronounced divergence in the plant community composition between the swards treated with NPK with or without slurry and the others can be mainly ascribed to the aforementioned characteristics of mineral fertilisers. Nitrogen from mineral fertiliser obviously played the pivotal role in this differentiation. A similarly rapid change of sward vegetation composition, subjected to different fertiliser treatments, is reported for the Park Grass Experiment (Silvertown et al., 2006).

The weak effect of slurry on the temporal community differentiation of sward compared to the unfertilised control is mainly the result of its application conditions: low to moderate application rate, surface spreading and usually hot summer weather during the second application. The latter two conditions most probably increased $\mathrm{N}$ losses $\left(\mathrm{NH}_{3}\right.$ volatilisation) and thus reduced the effect of this treatment on sward vegetation composition. The highest annual rate of $109 \mathrm{~kg} \mathrm{~N} \mathrm{ha}^{-1}$ applied by slurry was also below that one not to be detrimental for plant species richness of Arrhenatherion grassland (120 $\mathrm{kg} \mathrm{N} \mathrm{ha}^{-1}$ year $\left.{ }^{-1}\right)$ as reported by Duffková et al. (2015).

The peculiar pattern of plant community composition of the sward treated with PK can be mainly accounted to the strong positive effect of this fertilisation on legume growth. Such an effect is quite general regardless of the grassland community and is well supported by other studies (e.g. Gaujour et al., 2012; Kidd et al., 2017).

Cutting frequency affects plant community composition of sward in semi-natural grasslands less than fertilisation unless it is applied in agricultural relevant ranges (Socher et al., 2013). This was also confirmed in our study testing either temporal differentiation by DCA or differences among the treatments in the seventh experimental year by PERMANOVA. There was only one significant difference in plant community composition of the experimental swards, i.e. between traditional 2-cut and modified 4-cut systems. We expected a similarly strong effect between the most diverse traditional 2-cut and regular 4-cut systems, also suggested by the lists of ten most abundant species, but this was not the case. This again confirms that cutting regimes have less straightforward and profound effects on plant composition of swards than fertilisation regimes. However, different cutting frequencies (2 cuts $v s 4$ cuts per season) can significantly differ in their effects on vegetation composition in management condition to re-establish speciesrich grassland (Pavlů et al., 2011).

A high proportion of tall forbs did not occur in any treatment combination, which was also true for the one with a high input of NPK nutrients along with infrequent cutting. In such condition, however, a sward is likely to be susceptible to the encroachment of weeds, especially tall ones (Dietl, 1988).

\section{Functional groups (grasses, legumes and forbs)}

Evidence from literature and our practical experiences demonstrates that semi-natural grasslands managed for silage or hay production often suffer from a low proportion of legumes and, inversely, from a high proportion of forbs (Silvertown et al., 2006; Čop et al., 2009). Such grasslands hardly fulfil the criteria for optimal proportions of the functional groups, despite being realistic (50-70\% grasses, $10-30 \%$ for both legumes and forbs) (Dietl, 1982). The functional groups in this experiment were only affected by the fertilisation regimes. The most evident differences occurred, similarly as for the species composition, between the regimes where mineral $\mathrm{N}$ was added and the other regimes. Expectedly, the high $\mathrm{N}$ input increased markedly the proportion of grasses, while $\mathrm{N}$ absent in fertilisers or its low input favoured legumes at the expense of grasses (Figure 5). Forbs were less affected by the fertilisation regimes than other groups; however, as a result of the treatments, they differed markedly in plant species composition (Table 2). While the abovementioned effects are well known in literature and can be generalised for different types of semi-natural grasslands (e.g. Klapp, 1971; Silvertown et al., 2006), much less is known about the temporal patterns of the functional groups proportions in swards treated by different management regimes. Our analysis of these temporal patterns demonstrated a significant early effect (high $\mathrm{N}$ input $v s$ no or low $\mathrm{N}$ input) and significant annual variation, especially in the PK treated sward with increased legume proportion.

Reasonable cutting frequency for forage production in Arrhenatherion grasslands ranges between two to four per season. In some cases, this range is even narrower if the nutritional quality of forage may have been met. Therefore, the chosen cutting systems were similar and differed more in date of the first season cut than in defoliation frequency. We thus expected a weaker effect of this factor on the sward, which was later confirmed by the study. 


\section{Vegetation diversity parameters}

With an average of 28 vascular plant species per $10 \mathrm{~m}^{2}$, the experimental sward of Arrhenatherion grassland can be classified as moderately rich. The reported values from literature range mainly from 10 to 60 species per $100 \mathrm{~m}^{2}$ in managed grasslands (Wrage et al., 2011). The seven-year effect of fertilisation on species richness was not generally as negative as expected based on literature evidence for several medium to long-term experiments (e.g., Silvertown, 1980; Socher et al., 2013; Kidd et al., 2017) and even for short-term ones (Gough et al., 2000; Jacquemyn et al., 2003). The negative effect of fertilisation was conditioned on the rate of mineral $\mathrm{N}$ applied. It occurred only at the application of $220 \mathrm{~kg} \mathrm{~N}$ $\mathrm{ha}^{-1}$ year ${ }^{-1}$, which is partly in accordance with findings from the survey study by Zechmeister et al. (2003), where negative effect on plant richness occurred at $\mathrm{N}$ application of higher than $90 \mathrm{~kg}^{-1}$ year ${ }^{-1}$. All other fertilisation treatments did not affect species richness compared to the unfertilised control. The slurry application even indicated some positive effects (Figure 6), which can be mainly attributed to only modest improvement of $\mathrm{N}$ and $\mathrm{P}$ supply to the sward. Considering 35\% N use efficiency (Whitehead, 1995; Schröder et al., 2007), we estimate that slurry $\mathrm{N}$ uptake by the cut herbage was $20 \mathrm{~kg} \mathrm{ha}^{-1}$ year $^{-1}$ in the first four years and $38 \mathrm{~kg}$ $\mathrm{ha}^{-1}$ year $^{-1}$ afterwards. Phosphorus content in the soil, analysed in the autumn of the fifth experimental year, was higher for $11 \mathrm{mg}$ $\mathrm{kg}^{-1}$ compared to the unfertilised control (28 mg P kg-1 of dry soil). The fertilisation treatments had similar effects on Shannon index as on plant richness, yet the differences between the swards treated with mineral $\mathrm{N}$ and others are less pronounced, obviously due to higher plant evenness in the former group. The slurry application seems to be at least as beneficial for Shannon index as for plant richness. All these findings suggest that moderate fertilisation might not always have a deteriorating effect on species richness and Shannon index and that some fertilisation regimes have potential for improving both in Arrhenatherion grassland types.

The narrow-ranged cutting regimes were relatively ineffective in causing change in plant richness and Shannon index of Arrhenatherion grassland. There is only an indication that the traditional 2-cut system can be an advantage for plant richness and Shannon index compared to more intensive 4-cut systems (modified and regular). The similarly weak effect of agriculturally relevant cutting frequency on community diversity is also reported in literature (Klimek et al., 2007; Pavlů et al., 2011; Socher et al., 2013; Kramberger et al., 2015). It implies, therefore, that there is a scope for cutting regimes to meet both forage quality and diversity outcomes in Arrhenatherion grasslands without considerable compromise of either.

\section{Conclusions}

This study highlights the temporal differentiation of Arrhenatherion grassland vegetation caused by practically relevant fertilisation and cutting regimes. In a seven-year experiment period, more important differences occurred in plant composition than in plant richness and Shannon index. It was also found that fertilisation was a stronger factor influencing the investigated vegetation parameters than cutting, partly due to small differences in the cutting treatments. Generally, two distinct pathways of sward compositional development were found, dependent on whether the mineral $\mathrm{N}$ was added or not. In the first case, swards were composed considerably of productive grasses. In the second case, swards were composed considerably of rosette forbs. The sward treated with PK had the distinctive development of plant composition characterised by increased legume content and its noticeable variation among years. The effect of cutting regimes on sward compositional development was not significant. However, under longterm treatment, it can occur as suggested by the significant difference in the plant composition between traditional 2-cut and modified 4-cut systems in the seventh year. Functional abundance was only affected by fertilisation regimes where less intensive fertilisation (PK or slurry) or zero fertilisation improved this diversity compared to the more intensive one (NPK with or without slurry). However, forb proportions in swards of the first group sometimes reached or even exceeded the upper limit acceptable from an agronomic perspective, being more pronounced during the aftermath growth than the primary one. Considering the above mentioned groups, the differentiation of functional abundance increased with experimental progress but also indicates its quite high variation among the years. Temporal plant species richness and Shannon index were significantly affected only by fertilisation regimes, and only high $\mathrm{N}$ input reduced both. Slurry application indicated some positive effect on temporal plant richness and Shannon index compared to all other fertilisation regimes. We can conclude that moderately intensive management of Arrhenatherion grassland used for silage or hay can fulfil both agronomic and conservation requirements with an acceptable compromise between the both and that the intensity shift might mean some risk to the management sustainability and plant diversity of this type of grassland.

\section{References}

Bosshard A, 2015. Ruckgang der fromentalwiesen und die auswirkungen auf die biodiversitat. Agrar. Schweiz 6:20-7.

Chytrý M, Hejcman M, Hennekens SM, Schellberg J, 2009. Changes in vegetation types and Ellenberg indicator values after 65 years of fertiliser application in the Rengen Grassland experiment, Germany. Appl. Veg. Sci. 12:167-76.

Čop J, Vidrih M, Hacin J, 2009. Influence of cutting regime and fertiliser application on the botanical composition, yield and nutritive value of herbage of wet grasslands in Central Europe. Grass Forage Sci. 64:454-65.

DeMalach N, Zaady E, Kadmon R, 2017. Light asymmetry explains the effect of nutrient enrichment on grassland diversity. Ecol. Lett. 20:60-9.

Dickson TL, Gross KL, 2013. Plant community responses to long-term fertilisation: Changes in functional group abundance drive changes in species richness. Oecologia 173:1513-20.

Dietl W, 1982. Ökologie und Wachstung von Futterpflanzen und Unkräutern des Graslandes. Schweizerische Landwirtsch. Forschung 21:85-110.

Dietl W, 1988. Standort und Verbreitung der Kräuter in unseren Dauerwiesen. Schweizerische Landwirtsch. Forschung 27: 117-25.

Duffková R, Hejcman M, Libichová H, 2015. Effect of cattle slurry on soil and herbage chemical properties, yield, nutrient balance and plant species composition of moderately dry Arrhenatherion grassland. Agric. Ecosyst. Environ. 213:281-9.

Elberse WT, Van Den Bergh JP, Dirven JGP, 1983. Effects of use and mineral supply on the botanical composition and yield of old grassland on heavy-clay soil. Netherlands J. Agric. Sci. 31:63-88.

Egozcue JJ, Pawlowsky-Glahn V, Mateu-Figueras G, Barceló-Vidal C, 2003. Isometric Logratio Transformations for Compositional Data Analysis. Math. Geol. 35:279-300.

Galvanek D, Lepš J, 2008. Changes of species richness pattern in 
mountain grasslands: abandonment versus restoration. Biodivers. Conserv. 17:3241-53.

Gaujour E, Amiaud B, Mignolet C, Plantureux S, 2012. Factors and processes affecting plant biodiversity in permanent grasslands. A review. Agron. Sustain. Dev. 32:133-60.

Gough L, Osenberg CW, Gross KL, Collins SL, 2000. Fertilisation effects on species density and primary productivity in herbaceous plant communities. Oikos 89:428-39.

Hejcman M, Klaudisová M, Schellberg J, Honsová D, 2007. The Rengen Grassland Experiment: Plant species composition after 64 years of fertiliser application. Agric. Ecosyst. Environ. 122:259-66.

Hejcman M, Sochorová L, Pavlů V, Štrobach J, Diepolder M, Schellberg J, 2014. The Steinach grassland experiment: Soil chemical properties, swardheight and plant species composition in three cut alluvial meado wafter decades-long fertiliser application. Agric. Ecosyst. Environ. 184:76-87.

Hooftman DAP, Bullock JM, 2012. Mapping to inform conservation: a case study of changes in semi-natural habitats and their connectivity over 70 years. Biol. Conserv. 145:30-8.

Hülber K, Moser D, Sauberer N, Maas B, Staudinger M, Grass V, Wrbka T, Willner W, 2017. Plant species richness decreased in semi-natural grasslands in the Biosphere Reserve Wienerwald, Austria, over the past two decades, despite agri-environmental measures. Agric. Ecosyst. Environ. 243:10-8.

Jacquemyn H, Brys R, Hermy M, 2003. Short-term effects of different management regimes on the response of calcareous grassland vegetation to increased nitrogen. Biol. Conserv. 111:137-47.

Janssens F, Peeters A, Tallowin JRB, Bakker JP, Bekker RM, Fillat F, Oomes MJM, 1998. Relationship between soil chemical factors and grassland diversity. Plant Soil 202:69-78.

Jung V, Albert CH, Violle C, Kunstler G, Loucougaray G, Spiegelberger T, 2014. Intraspecific trait variability mediates the response of subalpine grassland communities to extreme drought events. J. Ecol. 102:45-53.

Kidd J, Manning P, Simkin J, Peacock S, Stockdale E, 2017. Impacts of 120 years of fertiliser addition on a temperate grassland ecosystem. PLoS One 12:1-26.

Klapp E, 1971. Wiesen und Weiden, fourth ed. Verlag Paul Parey, Berlin und Hamburg, Germany.

Klimek S, Richter KA, Hofmann M, Isselstein J, 2007. Plant species richness and composition in managed grasslands: The relative importance of field management and environmental factors. Biol. Conserv. 134:559-70.

Kramberger B, Podvršnik M, Gselman A, Šuštar V, Kristl J, Muršec M, Lešnik M, Škorjanc D, 2015. The effects of cutting frequencies at equal fertiliser rates on bio-diverse permanent grassland: Soil organic C and apparent N budget. Agric. Ecosyst. Environ. 212:1320.

Lepš J, 2014. Scale- and time-dependent effects of fertilisation, mowing and dominant removal on a grassland community during a 15year experiment. J. Appl. Ecol. 51:97887.

Pavlů V, Schellberg J, Hejcman M, 2011. Cutting frequency vs. N application: Effect of a 20-year management in LolioCynosuretum grassland. Grass Forage Sci. 66:50115.

Petersen U, Isselstein J, 2015. Nitrogen addition and harvest frequency rather than initial plant species composition determine vertical structure and light interception in grasslands. AoB Plants 7:plv089.

Pötsch E, 2008. Zur Wirksamkeit von Wirtschaftsdüngern im Grünland. pp 73-80 in Umweltökologisches Symposium, 4-5 March 2008.

R Core Team, 2017. R: A language and environment for statistical computing. R Foundation for Statistical Computing, Vienna, Austria.
Available from: https://www.R-project.org/

Ridding LE, Redhead JW, Pywell RF, 2015. Fate of semi-natural grassland in England between 1960 and 2013: a test of national conservation policy. Glob. Ecol. Conserv. 4: 516-25.

Schröder JJ, Uenk D, Hilhorst GJ, 2007. Long-term nitrogen fertiliser replacement value of cattle manures applied to cut grassland. Plant Soil 299:83-99.

Silvertown J, 1980. The Dynamics of a grassland ecosystem: botanical equilibrium in the park grass experiment. J. Appl. Ecol. 17:491-504.

Silvertown J, Poulton P, Johnston E, Edwards G, Heard M, Biss PM, 2006. The park grass experiment 1856-2006: its contribution to ecology. J. Ecol. 94:801-14.

Socher SA, Prati D, Boch S, Müller J, Baumbach H, Gockel S, Hemp A, Schöning I, Wells K, Buscot F, Kalko EKV, Linsenmair KE, Schulze ED, Weisser WW, Fischer M, 2013. Interacting effects of fertilisation, mowing and grazing on plant species diversity of 1500 grasslands in Germany differ between regions. Basic Appl. Ecol. 14:126-36.

Socher SA, Prati D, Boch S, Müller J, Klaus VH, Hölzel N, Fischer M, 2012. Direct and productivity-mediated indirect effects of fertilisation, mowing and grazing on grassland species richness. J. Ecol. 100:1391-9.

Soons MB, Hefting MM, Dorland E, Lamers LPM, Versteeg C, Bobbink R, 2017. Nitrogen effects on plant species richness in herbaceous communities are more widespread and stronger than those of phosphorus. Biol. Conserv. 212:390-7.

Tilman D, 1987. Secondary succession and the pattern of plant dominance along experimental nitrogen gradients. Ecol. Monogr. 57:189-214.

Tilman D, Dodd ME, Silvertown J, Poulton PR, Johnston AE, Crawley MJ, 1994. The park grass experiment: insights from the most longterm ecological study. In: R.A. Leigh, A.E. Johnston (Eds.), Longterm experiments in agricultural and ecological science. $\mathrm{CAB}$ International, Wallingford, Oxon., UK, pp 287-303.

van Dobben HF, Wamelink GWW, Slim PA, Kamiński J, Piórkowski $\mathrm{H}, 2017$. Species-rich grassland can persist under nitrogen-rich but phosphorus-limited conditions. Plant Soil. 411:451-66.

Vassilev K, Pedashenko H, Nikolov SC, Apostolova I, Dengler J, 2011. Effect of land abandonment on the vegetation of upland semi-natural grasslands in the western Balkan Mts., Bulgaria. Plant Biosyst. 145:654-65.

Waesch G, Becker T, 2009. Plant diversity differs between young and old mesic meadows in a central European low mountain region. Agric. Ecosyst. Environ. 129:457-64.

Wesche K, Krause B, Culmsee H, Leuschner C, 2012. Fifty years of change in Central European grassland vegetation: Large losses in species richness and animal-pollinated plants. Biol. Conserv. 150:76-85.

Whitehead DC, 1995. Grassland nitrogen. CAB International, Wallingford, UK.

Wrage N, Strodthoff J, Cuchillo HM, Isselstein J, Kayser M, 2011. Phytodiversity of temperate permanent grasslands: Ecosystem services for agriculture and livestock management for diversity conservation. Biodivers. Conserv. 20:3317-39.

WRB, 2015. World Reference Base for Soil Resources 2014, update 2015 International soil classification system for naming soils and creating legends for soil maps. World Soil Resources Reports No. 106. FAO, Rome, Italy.

Zechmeister HG, Schmitzberger I, Steurer B, Peterseil J, Wrbka T, 2003. The influence of land-use practices and economics on plant species richness in meadows. Biol. Conserv. 114:165-77. 